\title{
The Next Revolution Will Be In Education: A New Marketing Approach For Schools
}

\author{
Gavin Suss, Innovation Center - Keter Group
}

\begin{abstract}
The past 15 years have been a dramatic and unique period for education systems all over the world. The challenges have become more complex and the need for schools to promote their agenda has become cardinal and, in some cases, even critical. Today, parents, children, pupils and teachers are motivated by their senses and the positioning of leading brands in the market, including the educational market. As this is the reality, schools need to change their approach and develop a sense of marketing and branding in their DNA if they wish to survive this chaotic period (universities and colleges have engaged in marketing for years). This article will present a new approach for marketing schools and offer a strategic plan that every school can adopt and implement. Warner (2009) emphasizes that a strategic plan is the essential first step for the success of any school. It is time for schools to realize that they need to differentiate themselves and try to position their uniqueness (and if they do not have such a uniqueness, it's time to create it) in the system if they seek to lead and survive this "crazy" time. A series of interviews and data from open questionnaires was collected in Israel from principals and teachers and a qualitative analysis was conducted to define their views in relation to marketing schools. The main message in this paper is that schools are afraid of marketing, yet they need a marketing plan (Foster, 2011). Marketing is an essential part of a school district's communication plan, as it is in any successful business. If it is not, schools may find themselves out of business.
\end{abstract}

Keywords: Schools; Marketing; Branding; USP; Improvement; Change

\section{INTRODUCTION}

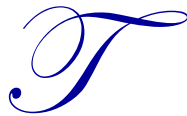

he 'history of education' is about the development of systematic methods of teaching and learning. Since the beginning of human existence, every generation has somehow passed on to the next generation its values, traditions, methods, and skills (Kendall and Murray, 2004). These were developed and advanced according to the needs of industry, society and technology; yet it seems that the past 15 years have created a need to change the traditional pattern of the history of education due to the internet revolution and technological changes. Schools today are faced with very critical and sophisticated clients - parents and children with endless information and opportunities seeking the best education. People place education as their top priority; they know that a healthy education system is vital for the life chances of their children (Hargreaves \& Fullan, 1998). In the past, teachers and schools had exclusive hegemony in knowledge and information, but today that has changed and the knowledge is available to all; there are more options and the clients (parents, pupils, or students and, in some cases, even the teachers) are on a quest for the best school and the best education.

According to Adizes (1990), every organization grows and develops according to a natural lifecycle, facing predictable problems at each stage along the way. This, of course, is not new, yet this paper suggests that schools today, due to the technological and information revolution, are like every business organization - they are born, they operate and live, produce and develop, and if they are not good enough or not strong enough, they will eventually become irrelevant and die. In the last 50 years, the lifecycle of organizations has proven that those that did not change, develop, and understand the dramatic developments in the open market failed and, in some cases, even disappeared. 


\section{The Need For Schools To Market Themselves}

You may have the best school, the best faculty, brilliant pupils, and great programs, but if schools don't expose those to as many people as possible, they might lose their potential "clients". Marketing schools successfully in today's highly competitive environment requires a decision by the school to engage in such a process and to manage it. School marketing is a way of doing things that express to pupils, parents, staff members, and the community that the school is dedicated to serving the educational needs of the community to the highest degree possible (Lockhart, 2011).

In 1990, Peters and Waterman published their bestseller book "In Search for Excellence". The book explores the art and science of management used by the leading 1980's companies with records of long-term profitability and continuing innovation. Surprisingly, some of those successful companies mentioned in the book were presented in another book published in 2007 named "The Self Destructive Habits of Good Companies". Its author, Sheth, mentions several companies and explains in the book why good companies fail and how they destruct themselves. Two of the main reasons are related to our human behavior and understanding; in other words, the leading managers of good companies, in their managerial decisions, were responsible for the failing outcomes. The two main reasons were arrogance and denial.

\section{Arrogance}

In the words of Sheth, "arrogance breeds in the dark, closed room; to break the habit, open the doors and windows and let the light shine in. The leader must change the culture to the one of looking, listening, and learning..."; for numerous reasons, managers are arrogant. It can be related to the personality of the manager, the legacy and culture of the company/school, tradition and even the success of the company/school. It doesn't matter; the result can be very dangerous for an organization/school. As presented in Sheth's book, some companies nearly went bankrupt and others just disappeared. In Israel, for example, many secondary and high schools have open registration; namely, pupils in the community/city can choose where to study and, according to the number of pupils, the school receives budgets and norms for teachers. This being the situation, schools can be closed and have been closed.

A manager that is not aware of the changes, the needs, and the developments in the open market shall fail. This is even more relevant in a changing internet market where within hours, a good company can lose billions if it receives negative coverage or if its competitor presents an advanced technology. The possibilities are vast and the one thing that managers have to be ready for is that "everything that can go wrong will go wrong". In this case, arrogance is a very problematic characteristic for managers and companies. Even in ancient Greek drama, arrogance - or Hubris - was the "tragic flaw". Along with arrogance, the second habit is denial. Like arrogance, this is a devastating habit that can destroy people, families, schools, companies, and even countries.

\section{Denial}

Denial has become one of the most dangerous and common reasons that cause people, relationships, and companies to fail. Some say that it is the root of most self-destructive habits nowadays. Based on the attention it gets from psychologists, it is clear that denial is a fundamental human response - a dependable defense mechanism used to avoid confronting painful truths (Sheth, 2007). In a series of interviews conducted during 2008 in Israel with 144 teachers and managers, a significant majority admitted that they preferred not to confront problems/incidents/parents and colleagues and chose to hope the issue will resolve itself. Research has found that denial is the biggest and potentially most ruinous problem that businesses face, encompassing all industries and areas, as well as schools.

Schools are becoming irrelevant; many are old and the internet and information revolution is leaving them behind. Budgets are low and the communities living near schools are not always aware of the important role that schools are still playing and need to play in the lives of the pupils. It's not that schools can't or are not doing a good job - it's just that they don't know how to market and promote themselves. In most cases, they don't believe they have to because they are "doing a good job" and that's good enough for them. Many education leaders and principals find thinking about the need to brand/market schools incorrect. Throughout the past decade in Israel, and 
in other countries too, the common response to the idea to "market schools" was negative and, in some cases, even worse. Lockhart (2011) reports that even teachers who were enthusiastic and recognized the benefits of marketing felt ill prepared for the task.

\section{What Has Changed That Requires Schools To Engage In Marketing?}

\section{Increased Competition}

Charter schools, schools of choice, home schools, for-profit schools which guarantee results, attacks from special interest groups, continued pressure for accountability, and the ongoing threat of vouchers all increase the need for public schools to market themselves. Lockhart (2011) claims that many different schools are seeking the same pupils - demand is smaller than supply.

Low Achievements Of The School System

Many parents are looking for alternatives due to the decline in the position and achievements of schools in the community.

\section{Changing Demographics}

For the past decades, the landscape of the family demographic status has changed. Today there are more single parent families, reducing the involvement of the parents in their children's education as they need to work more hours and have less time. Even in two-parent families, the lifestyle is conducted at such a speed that they lose control and don't know what's happening anymore.

“There's No News Like Bad News” in the system.

Usually only the bad actions and results of schools are published which weakens the trust of the community

\section{METHOD}

To understand the attitudes of principals and teachers to the idea of marketing schools and to conclude why many schools are not engaged in marketing, the managers and teachers were asked to complete an open questionnaire and participate in a lecture on the need for marketing/branding schools. Subsequently, they were interviewed. (In order to ensure that all of the participants were exposed to the idea of marketing and branding, in general, they needed to attend the lecture.)

\section{RESULTS}

Tables 1-3 present general data of the participants in this study for years employed as educators, age, and gender, respectively.

Table 1: General Data On The Participants Of This Study

\begin{tabular}{|c|c|c|c|c|}
\hline & & Age & Gender & Years in Education \\
\hline \multirow{2}{*}{$\mathrm{N}$} & Valid & 143 & 143 & 13 \\
\hline & Missing & 1 & 1 & 0 \\
\hline \multicolumn{2}{|c|}{ Std. Deviation } & .72735 & .49735 & .87522 \\
\hline \multicolumn{2}{|c|}{ Minimum } & 3.00 & 1.00 & 1.00 \\
\hline \multicolumn{2}{|c|}{ Maximum } & 5.00 & 2.00 & 3.00 \\
\hline
\end{tabular}


Table 2: Age Of The Participants Of This Study

\begin{tabular}{|c|c|c|c|c|}
\hline & & Frequency & Percent & Cumulative Percent \\
\hline \multirow{4}{*}{ Valid } & $26-28$ & 17 & 11.8 & 11.8 \\
\hline & 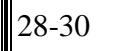 & 30 & 20.8 & 32.6 \\
\hline & $\mid$\begin{tabular}{||l}
$\mid 30+$ \\
$30+$
\end{tabular} & 97 & 67.4 & 100 \\
\hline & || Total & 144 & 100 & \\
\hline Missing & System & 0 & 0 & \\
\hline Total & & 144 & 100.0 & \\
\hline
\end{tabular}

Table 3: Gender Of The Participants Of This Study

\begin{tabular}{|c|c|c|c|c|}
\hline & & Frequency & Percent & Cumulative Percent \\
\hline \multirow{3}{*}{ Valid } & Male & 17 & 11.8 & 11.8 \\
\hline & Female & 127 & 88.2 & 100.0 \\
\hline & Total & 144 & 100 & \\
\hline Missing & System & 0 & 0 & \\
\hline \multicolumn{2}{|l|}{ Total } & 144 & 100.0 & \\
\hline
\end{tabular}

Table 4 shows that many principals and teachers think there is no need to market their school. This data matches the majority of employees in organizations that are not in favor of change. Sarason (1996) reviewed the influence of school culture on adopting change. In his opinion, schools will continue to impede efforts for change. The failure of change lies in the fact that those who support and those who oppose it are on a collision course. Sarason joins other education researchers who have determined that the existing patterns of change have been found to be inadequate (Berman \& McLaughlin, 1978; Goodlad, 1984), although some noteworthy changes have taken place during the last two decades (Shachar, Suss \& Sharan, 2010). Hargreaves and Fullan (1998) state that too much educational reform and restructuring is destroying teachers' confidence, draining their energy, eating up their time, and taking away their hope. This is just another concern and constraint when introducing schools to the need to change and start marketing themselves.

Table 4: Responses Of Principals (Includes Vice Principals And Heads Of Teaching Disciplines) and Teachers To The Question "Do Schools Need Marketing?"

\begin{tabular}{||l||c||c|}
\hline \multicolumn{1}{|c||}{} & Principals (n=22) & Teachers (n=122) \\
\hline \hline "Have to market" & 0 & 12 \\
\hline \hline "Need to market" & 2 & 9 \\
\hline \hline "Noybe market" & 9 & 93 \\
\hline
\end{tabular}

Table 5 includes statements that were repeated in the interviews with teachers and principals. The data were counted and analyzed and the results represent the statements that were repeated over 20 times.

Table 5 also clarifies that the majority of the principals and teachers find the need to market the schools irrelevant. Schools in Israel, especially secondary and high schools, are open for all pupils to register and there is competition among the schools over pupils, particularly the good ones. Those very "same clients" who belong to the technological generation and are influenced by the internet, brands and information, can be influenced by schools that promote and market themselves. 
Table 5: Frequency Of Responses Of The Principals And Teachers To The Idea Of Branding/Marketing Schools

\begin{tabular}{|c|c|c|}
\hline Statements & Principals $(n=22)$ & Teachers $(n=122)$ \\
\hline "We know we are doing a good job - I don't care what others say" & 10 & 85 \\
\hline "We are an education system - there is no place for marketing" & 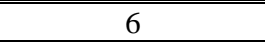 & 32 \\
\hline "It's hard enough teaching - now we need to sell ourselves" & 12 & 67 \\
\hline "Marketing is important but not in education" & 15 & 13 \\
\hline "No one will close our school so who needs it (marketing/branding)" & 7 & 35 \\
\hline "It can’t hurt, why not try?" & 3 & 17 \\
\hline "We don't know how to do it and we don't have money" & 16 & 98 \\
\hline
\end{tabular}

Some schools are in denial and some are demonstrating arrogance, thinking they can continue to operate as in the past, whilst the present is changing rapidly and the future is unknown.

The majority of teachers (80\%) and principals (72\%) stated, "We don't know how to do it and we don't have money". This paper will elaborate a simple, cheap and effective branding process that is especially designated for schools.

Sixty-nine percent of the teachers stated, "We know we are doing a good job - I don't care what others say". This is classical denial.

The results are not surprising and they indicate a cultural problem in schools in understanding the need to change for relevance and survival. "Our boss is changing" and it's time that schools understand this. The results are not encouraging, but they do represent a mirror and a need to operate if schools seek to remain relevant and survive.

\section{CONCLUSION}

Resistance to change in education (and in general) is a well-known phenomenon and is explained as part of the pain, anxiety, and ambivalence that teachers experience, along with the insecurity emanating from any program of comprehensive change. This causes teachers to prefer minimizing precarious situations and not accept changes, which threatens their security. Considering the institutional and professional conditions in the educational system and the pressures operating on schools from different directions, resistance to change is an expected and natural reaction (Shachar, Suss \& Sharan, 2010). However, organizations are changing because they have to do so if it their quest is to survive. Today it has become cardinal and, in some cases, a matter of life or death for organizations to conduct change (Suss, 2010).

The change offered here is dramatic, asking principals and teachers who are focused on education to start thinking in terms of marketing and branding, asking them to "sell" what they do for the community. These requests may seem simple, but for education people with values and ideology, it is a change in the culture of schooling and such changes are very problematic (Sarason, 1996). Having said that, it's about time schools comprehend that they are part of a changing network of technological systems and if they seek to survive, they must adopt some level of marketing/branding.

\section{RECOMMENDATIONS}

Adapt a new marketing approach!

For the past decade, the new buzz is "word of mouth"; in other words, the passing of information (recommendation) from person to person by oral communication. Word-of-mouth is a powerful marketing tool and it's free and very relevant for schools who cannot engage in traditional marketing and advertising and don't have the budgets. The skill is getting the right words spoken (Foster, 2011). According to Rosen (2000), marketing still focuses on how to use advertising and other tools to influence each customer individually, ignoring the fact that purchasing many types of products (education is a product) is part of a social process; namely, the process of 
marketing includes many exchanges of information and processes of influence among the people who surround the customers (parents and pupils).

This paper suggests a (strategic) plan, which is based on the understanding that schools should have an extraordinary characteristic/agenda/uniqueness that they can promote through word-of-mouth - not needing any budgets. They need to get the word out (Warner, 2009). Remember that nowadays, everyone is in marketing; schools need to be there too.

\section{The Strategy Offered Here Has Four Stages}

\section{Stage 1: Determine Goals}

It is cardinal to determine goals for the process and make sure they are:

1. $\quad$ Measurable - goals need to be quantifiable.

2. Specific - goals, which are not specific, are open to interpretation.

3. Attainable - make sure that the goals are realistic.

4. Time limit - have a framework of time to get the "job done".

\section{Stage 2: Vision of the Emotional Brand}

The management and staff of the school discuss and bring up a group of characteristics that best represent the school. These characteristics must be relevant and able to bring functional and emotional value, as well as benefit the parents and pupils (emotional as we are living in an emotional era). Foster (2011) talks about school marketing plan evaluation and the need for stakeholders to offer input. He mentions the principal, teachers, parents' representative, pupils' leaders, and more as options, yet one must remember that the more heterogeneous the team, the more difficult it will be to reach an agreed decision.

These characteristics are the Promise of the Brand; namely, they represent the agenda on which the school wants to brand itself. This will be the DNA of the school. At this stage, many ideas and characteristics are brought up by faculty and are all discussed. This process can continue several weeks, and at the end of the process, the school should have up to 10 potential ideas that can be the school's DNA. It is important that the majority of the faculty eventually agree with the final ideas.

\section{Stage 3: Visualization}

In the previous stage, the management and teachers brought up many ideas and characteristics. The top 10 ideas are now presented and a brainstorming session is conducted to identify the uniqueness and strengths of each characteristic and how it complies with the school. It is essential that the chosen characteristic will be easy to "sell" securing the school as an advantage. The main challenge is for the school to choose only one idea/characteristic which represents the uniqueness and is the most valuable one for the school, whilst differentiating this school from others in the district. This should be called the Core Characteristic (known as the USP - Unique Selling Point) and around it, a picture/visual should be built. It is important to enable as many staff members as possible to participate and it is even more important that the majority agree to the decision taken regarding the process of marketing (Warner, 2009). As schools do not have the resources and budgets to market themselves, they need to brand their major uniqueness through a visual picture that will "catch the eye and heart" of the clients.

Now that the school has one core characteristic that represents its DNA best (USP), and upon which the school faculty is in agreement, the school needs to visualize it so that it can be "sold" to the community. This requires a logo and a detailed marketing plan on how to promote the school's USP - core characteristic. 


\section{Stage 4: Management of the Core Characteristic (known as the USP)}

After the school has chosen the core characteristic that best represents its uniqueness, the final stage commences. This relates to the manner of managing the process and the USP. This process requires, above all, a dedicated team. A driving force behind any move for change in schools is the concept of shared decision-making (Warner, 2009). Likewise, the following are important too: time, an internet site, a newsletter, local campaigns to promote the school or, in other words, content marketing. Rose and Pulizi (2011), state, "Believe it or not, once there is an agreement to start content marketing, the biggest objection and fear isn't about the budget, success, or even reaching goals; it's "how are we actually going to get people to write this stuff". Teachers and principals involved in the process need to learn how to write content that will support and strengthen the USP. Likewise, they should learn how to promote the content in the funnels of the school and community.

This is a very important stage, as it will determine how the school is positioned in the minds of the clients and its unique selling point in the future.

This strategy is simple, yet effective and cheap. It can help develop positive relations with the media (Foster, 2011) which can help the school develop a healthy dialogue with the community. The more the market and community are exposed to positive information regarding the school, the quicker the school and its USP will be positioned in the minds and heart of the clients. This will lead to the branding of the school around its USP. Figure 1 presents the process described above - from a brainstorm of many ideas and characteristics to choosing one core characteristic that the staff members agree upon - and then it's all about managing it.

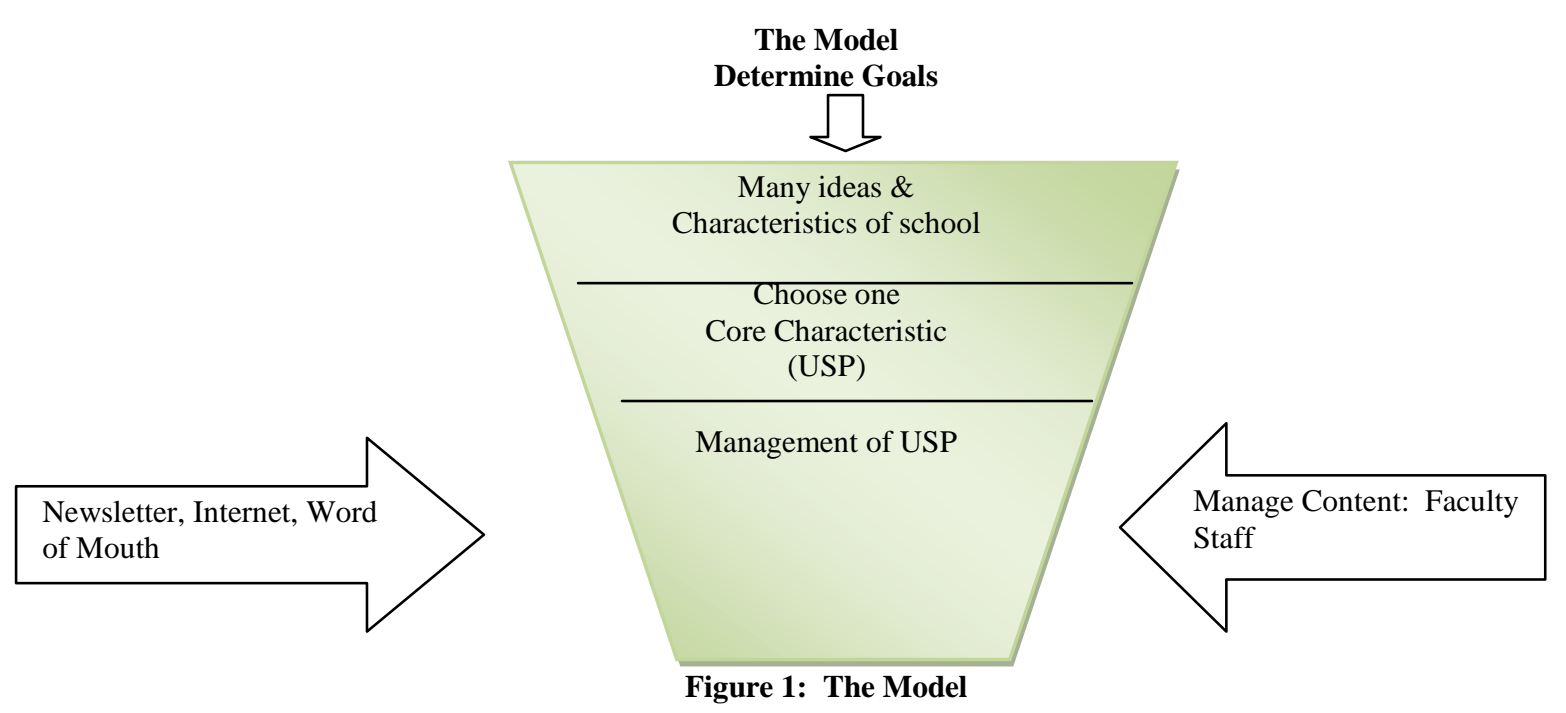

Every school has a position, whether it markets itself or not. This is a result of its educational and social legacy and activity in the community. The process suggested above requires schools to make a positioning statement. The statement dictates how the school will be perceived by its clients; in other words, its unique selling point - its brand. This is the next revolution in education - a revolution that is cardinal due to the technological changes - and "it's about time" schools adopt a market approach along with their educational agenda.

\section{AUTHOR INFORMATION}

Gavin Suss was born in South Africa, and immigrated to Israel with his family at the age of 9. He has a Ph.D. in Education and Management from Tel Aviv University. He engages in the fields of education, innovation, personal development and empowerment of people, and is considered a popular lecturer in academic institutions in Israel and abroad. For years he served as the academic director at the acclaimed Design and Engineering College Shenkar. He was elected as executive director of the High Committee of Public Colleges in 2006, and served as a Director of the Central Archive for the History of the Jewish People. He is VP Corporate Educator at Keter Plastic and teaches at 
the Tel Aviv University in the MBA program at the Recanati Business School. He has published several academic articles and recently published his first book WAKE UP: you only live once. E-mail: gavin.suss@keter.co.il

\section{REFERENCES}

1. $\quad$ Adizes, I. (1990) Managing Corporate Lifecycles. Prentice Hall Press; Revised edition.

2. Berman, P \& McLaughlin, M.W (1977) Making a Difference: Teacher's Sense of Efficacy and Student Achievement. Longman.

3. Foster, (2011) School Marketing Media for the Digital Age. Great Developments Pty Ltd.

4. Goodlad, J. I. (1984) A Place Called School: Prospects of the Future. New York: McGraw-Hill.

5. Hargreaves, A \& Fullan, M (1998) What's Worth Fighting for Out There. Teachers College Press.

6. Kendall D, Murray J \& Linden, R (2004) Sociology In Our Times. Third Canadian Edition, Nelson Education Ltd.

7. Lockhart, J (2011) How to Market Your School. A Guide to Marketing, communication, and Public Relations for School Administrators. Rowman and Littlefield Education.

8. $\quad$ Peters T. J \& Warterman, R H (1982) In Search for Excellence. HarperCollines Publishers.

9. Rose, R and Pulizzi, J (2011) Managing Content Marketing, The Real - World Guide for Creating Passionate Subscribers to your Brand.CMI Books.

10. Rosen, E (2000) The Anatomy of Buzz. Doubleday.

11. Sarason, S (1996) Revisiting "The Culture of School and the Problem of Change". Teachers College Press. Columbia University.

12. Shachar, H. Suss, G\& Sharan, S (2010) Changing organizational culture and instructional methods in elementary schools: Perceptions of teachers and professional educational consultants. Journal of Educational Change. Vol, 11, Number 3, pp. 273-289.

13. Sheth, J. N (2007) The Self Destructive Habits of Good Companies. Wharton School Publishing.

14. Suss, G (2010) d-Vision: Seeking Excellence Through a Hands on Engineering Multi Discipline Global Internship Program. American Journal of Business Education. Vol 3, Number 4, pp. 99-104.

15. Warner, C (2009) Promoting your School. Going beyond PR. Crowin. 